\title{
A gyermektelenség mintázatai magyar férfiak körében: egy interjús vizsgálat folytatása'
}

\author{
Szalma Ivett-Takács Judit \\ https://doi.org/10.51624/SzocSzemle.2018.3.4 \\ Beérkezés: 2018. 06. 28. \\ Átdolgozott változat beérkezése: 2018. 11. 20. \\ Elfogadás: 2018. 11. 26.
}

\begin{abstract}
Összefoglaló: Ebben a tanulmányban azt vizsgáltuk, hogy milyen tényezők játszhatnak szerepet abban, ha egy férfi nem vállal gyermeket ma Magyarországon. Továbbá arra a kérdésre is próbálunk választ adni, hogy vajon eltérő gyermektelenségi mintázatok figyelhetők-e meg a férfiak és a nők között Magyarországon. Jelen kutatás szervesen kapcsolódik korábbi, elsősorban gyermektelen nőkre fókuszáló kutatásainkhoz, melyeket most kiegészítünk a magyar férfiakra fókuszáló vizsgálatunkkal.

A kutatás empirikus alapja egy 50 év feletti gyermektelen férfiakkal készített félig strukturált interjús vizsgálat, amelyet 2015 és 2016 között végeztünk különböző típusú magyarországi településeken. Kutatási eredményeink arra világítanak rá, hogy a férfiak és a nők gyermektelensége mögött gyakran eltérő tényezők húzódhatnak meg, illetve az azonos tényezők mögött is eltérő mechanizmusok müködhetnek.
\end{abstract}

Kulcsszavak: gyermektelenség, férfiak, kvalitatív vizsgálat, összehasonlítás a női gyermektelenségi mintázatokkal, Magyarország

\section{Bevezetés}

Korábbi kvalitatív kutatásunkban 40 év feletti gyermektelen nőket kérdeztünk meg egy interjús vizsgálat keretében, hogy feltárjuk, milyen okok vezethetnek az akaratlagosan vagy nem akaratlagosan megvalósuló gyermektelen életmódként értelmezett gyermektelenséghez a nők körében Magyarországon (Szalma-Takács 2014). Ennek a kérdésnek a vizsgálata azért érdemel figyelmet, mert a kvantitatív survey vizsgálatok eredményei azt jelzik, hogy hazánkban kevesen vannak, akik tudatosan nem szeretnének gyermeket vállalni. Például a 2010-es Eurobarometer adatai szerint Magyarországon $17 \%$ a gyermektelen nők és $25 \%$ a gyermektelen férfiak aránya a 30-45 éves korosztályban, miközben a tudatosan gyermektelenek aránya ugyanebben a korcsoportban mindössze 2-3\% között mozog a nők és a férfiak körében egyaránt (Miettinen-Szalma 2014). Nemzetközi összehasonlításban vizsgálva ezeket az adatokat az látszik, hogy a gyermektelenek aránya alacsony Magyarországon, illetve az egész posztszocialista régióban elmarad a nyugati társadalmakban megfi-

1 A tanulmány megírását az NKFIH (PD 123789) támogatta. 
gyelhető arányoktól. Ugyanez igaz a gyermektelen életmódot tudatosan választókra is: míg a posztszocialista régióban arányuk $4 \%$ alatti, addig a nyugati országokban 5-10\% között mozog (Miettinen-Szalma 2014). Az attitűdök tekintetében hasonló eredményt talált Merz és Liefbroer (2012), akik a European Social Survey harmadik hullámának adatain azt vizsgálták meg, mennyire tekinti egy adott társadalom elfogadhatónak azt, ha valaki tudatosan nem vállal gyermeket: a legalacsonyabb elfogadást Lengyelországban, Szlovákiában, Magyarországon, Litvániában, Romániában, Észtországban és Bulgáriában találták, ahol a kérdezettek több mint fele szerint elfogadhatatlan a tudatosan választott gyermektelen életmód.

Mindazonáltal Magyarországon növekszik a gyermektelenek aránya: a 2001-es cenzus adatai szerint a 41 év feletti nők körében a gyermektelenek aránya 7,8\% volt, ami 2011-re 11,2\%-ra növekedett (Kapitány 2015). A férfiakra vonatkozóan pontatlanabb adatok állnak rendelkezésünkre a cenzus alapján, mivel a férfiak szülővé válása kevésbé kötődik életkori korlátokhoz, illetve normákhoz, mint a nők gyermekvállalása (Szalma 2014), valamint az is előfordulhat, hogy a férfiak esetenként nem is tudnak arról, hogy gyermekük született. Ennek ellenére a cenzus adatai alapján a körükben nemcsak magasabb a gyermektelenek aránya, mint a nők körében, hanem gyorsabb ütemben is növekszik: a 41 és 45 év közötti korcsoportban ez az arány 17\% volt 2001-ben és 22\% lett 2011-ben (Kapitány 2015).

A számok tükrében jogosan merül fel a kérdés: vajon miért forditunk kevesebb figyelmet a férfiak körében a gyermektelenség vizsgálatára? Az egyik lehetséges válasz erre, hogy a gyermekvállalás kérdését hajlamosak vagyunk a nőkhöz rendelni, ami a férfi törődésdeficit társadalmi normalizálásával hozható összefüggésbe. Az adott társadalmi közegre jellemző férfiasság- és nőiességnormák vizsgálata alapján elmondható, hogy több más országhoz hasonlóan a gyermekekkel - és más rászoruló családtagokkal - való törődés révén a nők a társadalmilag előírt nőiesség formáit teljesíthetik ki Magyarországon is, míg ez az elvárás a férfiak felé kevéssé érvényesül (bár például aktívan törődő apákkal itthon is növekvő számban találkozhatunk erről lásd pl.: Takács [2017]). A gyermekvállalás és a gyermektelenség témái ezért a közbeszédben gyakran úgy kerülnek elő, mintha szinte kizárólag női felelősségkörökbe tartoznának: erre jó példa a 2018-ban „demográfiai fókuszú kormányzást”" meghirdető magyar miniszterelnök nyilatkozata arról, hogy szeretne „egy átfogó megállapodást kötni a magyar nőkkel, mert a demográfia végül is rajtuk áll vagy bukik [...] mert a gyerekvállalás [...] a legszemélyesebb közügy, és ezt csak a hölgyek tudják eldönteni”. ${ }^{3}$

2 Forrás: http://www.kormany.hu/hu/a-kormanyszovivo/hirek/folytatodik-a-nemzetnek-es-a-csaladoknak-kedvezo-kormanyzas (2018. április 11.).

3 Forrás: http://www.kormany.hu/hu/a-miniszterelnok/beszedek-publikaciok-interjuk/orban-viktor-a-kossuth-radio-180-perccimu-musoraban20180420 (http://www.kormany.hu/hu/a-kormanyszovivo/hirek/folytatodik-a-nemzetnek-es-a-csaladoknakkedvezo-kormanyzas (2018. április 20.). 
Emellett kétségtelen, hogy nehezebb meghatározni, mikortól tekinthető ténylegesen gyermektelennek egy férfi, mivel a férfiak szülővé válása a nőkhöz képest kevésbé kötődik életkori korlátokhoz és normákhoz; valamint a gyermektelenséggel kapcsolatban esetenként a kérdőíves kutatások is pontatlanabb adatokkal szolgálhatnak a férfiakról, mint a nőkről (például egyes férfiak esetleg nem is tudnak arról, hogy gyermekük született, vagy előfordulhat, hogy elfelejtik megemlíteni a nem velük egy háztartásban élő gyermeküket egy kérdőíves adatfelvétel során). A gyermektelenség kérdéskörét tárgyaló nemzetközi demográfiai, illetve társadalomtudományos szakirodalomra is jellemző, hogy több tudományos publikáció foglalkozik kiemelten vagy kizárólag a nőkkel, mint a férfiakkal. Például a gyermektelenségre fókuszáló két, közelmúltban megjelent nemzetközi tanulmánykötetben is többségbe kerültek az olyan tanulmányok, melyek csak a nők körében vizsgálták a gyermektelenséggel összefüggő tényezőket (Kreyenfeld-Konietzka 2017; Sappleton 2018).

Ugyanakkor a gyermektelen férfiak közelebbi vizsgálata több okból is figyelmet érdemel: azon túl, hogy többen vannak, mint a gyermektelen nők, azért is fontos e téma vizsgálata, mert a kvantitatív vizsgálatok arra is rámutattak, hogy a férfiak esetében eltérő okok játszhatnak szerepet a gyermektelenség kialakulásában, mint a nőknél. Például míg a nők körében a magasabb iskolai végzettség növeli a gyermektelenség valószínűségét, addig ez a férfiaknál inkább a gyermekvállalás valószínűségét növeli (Keizer et al. 2008; Szalma-Takács 2015, 2018). E mögött az állhat, hogy a magasabb iskolai végzettségű nők körében a gyermekvállalás nagyobb alternatív költséggel járhat, mint az alacsonyabb iskolai végzettségű társaiknál: a kisgyermekgondozási feladatok hosszabb-rövidebb ideig megszakíthatják a munkapiacon jelen lévő nők karrierjét. Ebben a tekintetben a munkavállalás és a gyermekvállalás két egymással versengő életesemény a nők életében (Matysiak 2011). Ez a közgazdasági logika azonban kevéssé érvényesül a férfiak körében, hiszen az ő munkapiaci karrierjükre a gyermekvállalás nincs negatív hatással, mivel ritkán fordul elő Magyarországon, hogy az apák maradnának otthon a kisgyermekükkel (Makay 2015; Takács 2017). Sőt egyes kutatások ennek éppen az ellenkezőjét mutatják, azaz a férfiak karrierjét az apává válás még elő is mozdíthatja azáltal, hogy - a női partnerek kiesett jövedelmét pótolni igyekezve - gyakran akár túlmunkát is vállalnak (Matysiak-Steinmetz 2008; Hobson-Fahlén 2009; Hobson et al. 2011). Ezzel párhuzamosan a munkapiaci helyzetnek is fordított hatása mutatható ki: férfiak esetében a biztos munkapiaci helyzet csökkenti, a nők körében viszont növeli a gyermektelenség esélyét (Gonzáles-Jurado-Guerrero 2006; Keizer et. al 2008; Barthold et. al 2012; Fieder et. al 2011). Ugyanakkor megemlítendő, hogy a posztszocialista országokban végzett vizsgálatok a munkapiaci helyzet tekintetében eltérő eredményeket hoztak: a stabil munkapiaci helyzet (teljes állás és határozatlan idejû foglalkoztatás) növelheti a gyermekvállalás esélyét a nők körében is (Szalma 2011; MatysiakVignoli 2013) - ennek hátterében a posztszocialista országokra jellemző kétkeresős 
családmodell elterjedtsége állhat, ugyanis ritka, hogy egy kereső el tudja tartani a családot (Szalma 2011).

A férfiak gyermektelenségével foglalkozó vizsgálatok alulreprezentáltsága mellett a gyermektelenség lehetséges okait vizsgáló kutatások legtöbbje az angolszász és a német ajkú országokra fókuszál. A posztszocialista régióban a gyermektelenség témaköre alulkutatott: kivételként lengyel (pl. Mynarska et al. 2015), cseh (pl. Haskova 2011) és magyar (Szalma-Takács 2012, 2014, 2015, 2018) példák említhetők. Ugyanakkor feltételezhető, hogy eltérő okok húzódnak meg a gyermekek (nem) vállalása mögött a különböző régiókban.

A gyermektelenség eltérő mintázatai a nők és a férfiak körében, valamint Európa egyes társadalmaiban azt jelzik, hogy érdemes megvizsgálni, vajon milyen tényezők állhatnak a férfiak gyermektelenségének hátterében Magyarországon. Jelen tanulmánnyal célunk nem csak az, hogy áttekintsük a férfiak gyermektelenségét potenciálisan meghatározó tényezőket, hanem emellett reflektálni szeretnénk a nemek szerinti különbségekre és a magyar társadalom sajátosságaira is.

\section{Kvalitatív megközelítés: minta és módszer}

Kvalitatív vizsgálatunk keretében 2015 és 2016 között 30 félig strukturált interjút készítettünk gyermektelen heteroszexuális férfiakkal egy európai kutatási projekt keretében. ${ }^{4}$ A mintavétel során a heteroszexuális orientáció szelekciós kritériumként való alkalmazása nem csak a korábbi női interjúk eredményeivel való összevethetőség miatt vált szükségessé, hanem azért is, mert a meleg férfiak gyermek-(nem) vállalásának kérdéskörét meghatározzák az azonos nemű párok gyermekvállalását több szempontból korlátozó rendelkezések, melyek heteroszexuális társaikat kevéssé vagy egyáltalán nem érintik. Ezt a fajta gyermektelenséget egy korábbi tanulmányunkban a társadalmilag előírt gyermektelenség egyik formájaként értelmeztük: e kategóriába sorolva mindazokat, akiknek valamely sajátságuk - pl. mentális vagy egyéb betegségük - miatt olyan szabályokkal és intézkedésekkel kell szembesülniük, melyek korlátozzák termékenységüket, illetve gyermekvállalási lehetőségeiket (Szalma-Takács 2014).

A mintába kerülés kritériumait életkori szempontból úgy határoztuk meg, hogy interjúalanyaink 50 évesek vagy annál idősebbek legyenek; felső korhatárt nem szabtunk meg, de ügyeltünk rá, hogy lehetőleg minél több korcsoportból kerüljenek a mintába. Településtípus, iskolai végzettség és családi állapot tekintetében nem szabtunk meg konkrét szelekciós kritériumokat. A potenciális interjúalanyokhoz egyrészt a nyomtatott és az elektronikus médiatermékekben, illetve online fóru-

4 Családok és társadalmak: Változó családok és fenntartható társadalmak - szakpolitikai háttér és sokszínüség az életutak és a generációk mentén (Families and Societies - Changing families and sustainable societies: Policy contexts and diversity over the life course and across generations) kutatási együttmüködés az EU 7. Keretprogramjában (2013-2017), http://www. familiesandsocieties.eu/ - Az interjúk készítésében Vajda Róza is részt vett, akinek közreműködését ezúton is köszönjük. 
mokon elhelyezett hirdetések útján, másrészt - ahol erre lehetőség nyílt - hólabda módszerrel jutottunk el.

Az 50 éves korhatár megadását azok a statisztikai adatok indokolták, melyek szerint ezen életkor fölött már ritkán válik egy férfi először apává Magyarországon, ahogy ez az 1. ábrán is jól látható. Interjúalanyaink több mint kétharmada (26-an) egyedülálló volt, közülük hárman korábban házasságban éltek, de az interjúkészítés idejére már elváltak; négyen pedig párkapcsolatban éltek: közülük egy férfi élt házasságban, egy élettársi kapcsolatban, ketten pedig LAT-kapcsolatban. ${ }^{5}$

\section{1. ábra: Nők és férfiak korspecifikus termékenységi arányszámai 2000-ben}

0,12

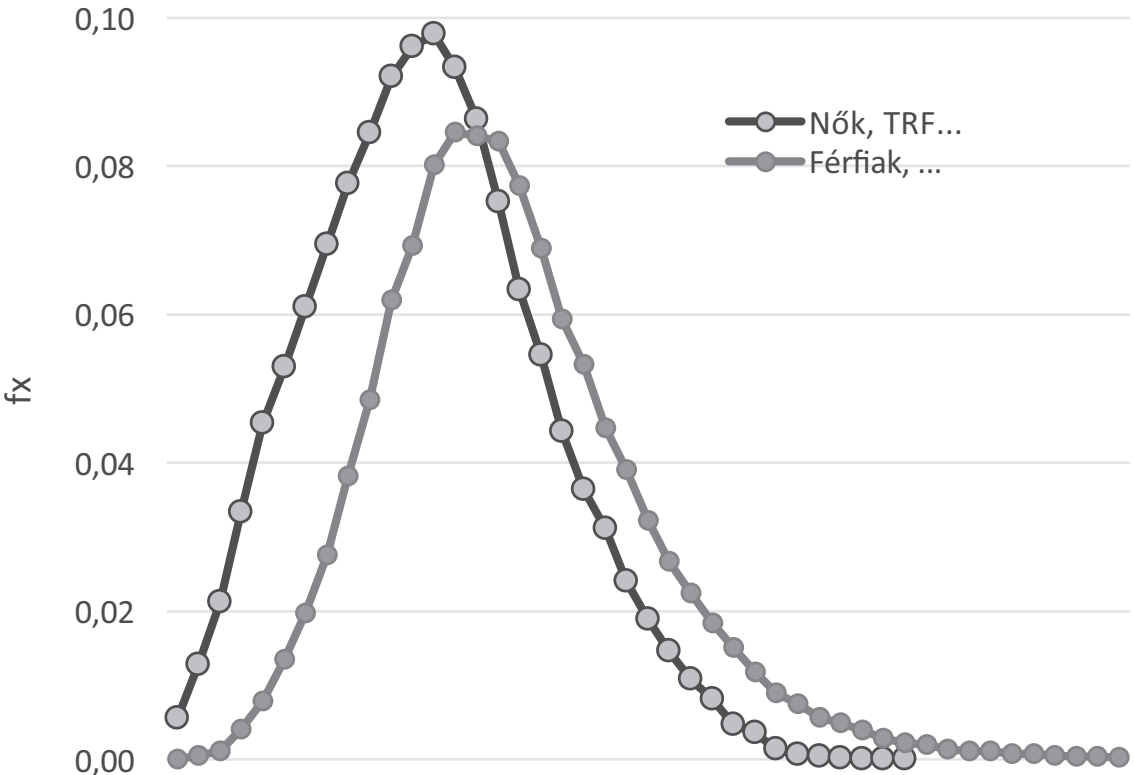

1517192123252729313335373941434557495153555759

Forrás: Daróczi 2001: 14

Interjúalanyaink közé eltérő településtípusokból (a fővárosból, valamint vidéki városokból és falvakból) származó, különböző iskolai végzettségű (alacsony végzettsé-

5 ALAT-kapcsolat elnevezés a'living together apart'angolkifejezés rövidítését tartalmazza. Magyarul látogató párkapcsolatoknak is nevezhető: külön háztartásokban élő partnerek tartós és kizárólagos párkapcsolatai (a LAT-kapcsolatokról bővebben lásd: Kapitány [2012]).

6 Tudomásunk szerint ez volt az első és eddig egyetlen alkalom, amikor férfiakra vonatkozó termékenységi arányszámokat közöltek Magyarországon. Köszönettel tartozunk Daróczi Etelkának, aki felhívta figyelmünket erre az adatsorra. 
gű, azaz: érettségi nélküli; érettségizett; és magas iskolai végzettségű) férfiak kerültek. S bár arra törekedtünk, hogy mindhárom településtípus, illetve iskolai végzettségi kategória egyaránt jelen legyen mintánkban, a magasabb iskolai végzettségűek, a fővárosban élők és az egyedülállók kerültek többségbe. ${ }^{7}$ A mintánk összetételét összefoglaló 1. táblázatból ugyanakkor jól látszik, hogy sikerült - a kutatók számára általában kevésbé hozzáférhető és különösen az érzékeny témák tekintetében nehezebben szóra bírható - alacsonyabb iskolai végzettségű, vidéki kistelepüléseken élőket is elérnünk: interjúalanyaink több mint fele maximum érettségivel rendelkezik és egyharmada faluban él.

1. táblázat: A minta összetétele iskolai végzettség, lakhely és partnerkapcsolat-típus szerint

\begin{tabular}{c|c|c|c|c|c} 
Iskolai végzettség & $\begin{array}{c}\text { Interjúalanyok } \\
\text { száma }(\mathbf{n})\end{array}$ & Település típus & $\mathbf{( n )}$ & Partnerkapcsolat & $\mathbf{( n )}$ \\
\hline Alacsony & 10 & Budapest & 16 & Egyedülálló & 23 \\
\hline Közepes & 8 & Város & 5 & Házas & 1 \\
\hline Magas & 12 & Falu & 9 & Elvált & 3 \\
\hline Összesen & 30 & Összesen & 30 & Élettársi kapcsolat & 1 \\
\hline & & & & LAT kapcsolat & 2 \\
\hline & & & & Összesen & 30
\end{tabular}

Forrás: saját szerkesztés az elkészült 30 interjú alapján

A félig strukturált életútinterjúk készítése előtt tájékoztatáson alapuló beleegyezési nyilatkozatott kértünk és kaptunk a kutatás résztvevőitől, majd felkértük őket, válasszanak maguknak egy kitalált nevet annak érdekében, hogy anonimitásukat megőrizve tudjuk a hozzájuk köthető kutatási anyagokat azonosítani a későbbiekben. (E tanulmányban is ezek a nevek szerepelnek, amikor interjúalanyainkra utalunk vagy őket idézzük.) Ezután egy rövid kérdőív segítségével összegyüjtöttük az interjúalanyok demográfiai jellemzőit, valamint egy külön önkitöltős kérdőív keretében rákérdeztünk reprodukciós történetükre: többek között arra is, hogy tudomásuk szerint nehezítette-e valamilyen egészségi probléma a gyermekvállalásukat. Mintánkba csak olyan interjúalanyok kerültek, akiknek nem volt tudomása ilyen egészségi problémáról.

$\mathrm{Az}$ átlagosan másfél óra hosszúságú interjúk vezérfonala öt területet fedett le. Ezek a következők voltak: 1. gyermekkori családi jellemzők, 2. a családok életében bekövetkezett változásokkal kapcsolatos vélemények és attitűdök, 3. munkavállalás-történet, 4. párkapcsolat-történet; valamint 5. jövőbeli tervek. Az interjúk hangfelvételeiről szó szerinti leírások készültek (a hangfelvételeket ezután megsemmisítettük), s a leírt szövegek strukturális kódolása alapján létrejött kódkönyv szolgált elemzésünk alapanyagául.

7 A női gyermektelenségi mintázatokkal foglalkozó korábbi vizsgálatunkban (Szalma - Takács 2014) is az ilyen szocio-demográfiai háttérrel rendelkező interjúalanyok voltak felülreprezentálva. 
Kvalitatív feltáró vizsgálatunk során arra törekedtünk, hogy minél teljesebb képet alkossunk interjúalanyainknak a saját gyermektelenségükkel kapcsolatban konstruált, egyénileg változó magyarázó modelljeiről, azaz, hogy milyen módon magyarázzák a gyermektelenségüket meghatározó tényezőket. Kutatásunk egyik fő célja, hogy a rendelkezésre álló interjúkból olyan mintázatokat tárjunk fel, melyek feltehetően hozzájárultak ahhoz, hogy a vizsgált életutakban nem került sor gyermekvállalásra. Az interjúkban fellelhető közös jellemzők mintázatainak korábbi kutatások eredményeivel való összevetése révén jutottunk az itt közölt eredményekhez.

\section{Eredmények}

Korábbi kvantitatív és kvalitatív kutatási eredményeinkből kiindulva (Szalma-Takács 2012, 2014, 2015, 2016, 2018) azt vizsgáltuk meg, hogy vajon az általunk korábban - elsősorban a nők körében - feltárt mechanizmusok mennyibe játszanak szerepet a férfiak gyermektelenségében. Ezzel összefüggésben felidézhetjük a magyar gyermektelen nőkre fókuszáló kvalitatív vizsgálatunk konklúzióját, ahol azt hangsúlyoztuk, hogy „a tartós vagy végleges jellemzőként megjelenő gyermektelenség ritkán vezethető vissza egyetlen okra vagy egyetlen döntésre: a gyermektelen állapot egy komplex folyamat eredménye, amelynek során több faktor hat egymásra" (Szalma-Takács 2014: 131). Ha szétszálazzuk ezt a komplex folyamatot, akkor az általunk vizsgált magyar nők körében a gyermektelenség mögött meghúzódó legfőbb okok között a következőket találjuk: a stabil párkapcsolat hiánya; életkori korlátok (utalással arra, hogy túl idős már a gyermekvállaláshoz: kifutott már a gyermekvállalás biológiailag vagy szubjektív megítélések alapján adottnak vélt időintervallumából), anyagi nehézségek (nincs stabil munkája, vagy túl rossz anyagi körülmények között él). A következőkben először ezeket a tényezőket vesszük közelebbről szemügyre a férfiak beszámolói alapján.

\section{Mennyiben játszik szerepet a (jó minőségü) partnerkapcsolat hiánya?}

Számos korábbi nemzetközi tanulmány rávilágított arra, hogy a partnerkapcsolat hiánya nemcsak a nőknél játszik kiemelkedő szerepet a gyermektelenséghez vezető úton, hanem a férfiak gyermektelenségéhez is jelentősen hozzájárulhat (lásd pl. Hollandiára: Keizer et al. [2008]; Angliára: Berrington [2004, 2017] és Finnországra: Jalovaara-Fasang [2017]). Miközben a nőkkel végzett interjús vizsgálatunk ezt az eredményt megerősítette (Szalma-Takács 2014), addig a férfiaknál képlékenyebbnek mutatkozott a párkapcsolat és a gyermektelenség közötti összefüggés.

A vizsgált férfiak többsége arról számolt be, hogy élete során volt legalább egy tartós párkapcsolata, és számos rövidebb ideig tartó kapcsolattal is rendelkeztek: e partnerkapcsolatokon belül több olyan gyermekvállalást akadályozó tényező merült fel a körükben, amelyeket a nők esetében nem tudtunk megfigyelni. Az egyik ilyen 
lehetséges akadály, ha idősebb párt választottak, akinek már biológiailag nem lehetett gyermeke. Másfajta nehézséget jelentett az is, ha a partnerük, akinek volt(ak) már gyermeke(i), nem szeretett volna több gyermeket vállalni.

Különösen az alacsonyabb iskolai végzettségű férfiak számoltak be ezekről az akadályokról: például a 62 éves, alacsony iskolai végzettségú, egyedülálló, falun élő Márton elmondta, hogy 45 éves korában találkozott akkor már 51 éves élettársával, így nem is jöhetett volna szóba gyermekvállalás. Ilyen helyzetekben az örökbefogadás gondolata is csak ritkán merült fel: a hagyományos biológiai-vérségi kapcsolatokon és a biológiai szülőség prioritásán alapuló nukleáris családtól eltérő módon - például örökbefogadással - létrejövő, társadalmilag konstruált szülőség- és családfogalom még kevéssé tűnik elfogadottnak a magyar társadalomban (NeményiTakács 2015). Az általunk korábban vizsgált gyermektelen nők is (különösen az idősebbek) a férfiakhoz hasonlóan a biológiai szülőséget preferálták; azok a nők pedig, akik hajlottak volna arra, hogy örökbefogadás útján váljanak szülővé, gyakran éppen azért vetették el ezt a gondolatot, mert nem éltek párkapcsolatban, és egyedülállóként nem mertek belevágni az egyszülős családalapításba.

Az 55 éves, szintén alacsony iskolai végzettségü, falun élő, házas Béla is azt hangsúlyozta, hogy ő szeretett volna saját gyereket, mert ő a vérségi kapcsolaton alapuló szülő-gyermek kapcsolatot tartja „igazinak”. Mivel azonban a feleségének az előző házasságából már született három gyermeke, így Béla elfogadta, hogy az asszony nem akar több gyermeket vállalni. Annak ellenére, hogy a férfi aktívan részt vett mind anyagi, mind érzelmi támogatással felesége gyermekeinek nevelésében, sohasem gondolt rájuk úgy, mint saját gyermekeire.

Hasonló helyzetben érezte magát a 62 éves, élettársi kapcsolatban élő Zoltán, bár az ő partnerének korábbi kapcsolatából csak egy gyermeke származott, és nyitott is lett volna egy közös gyermekre. Azonban - valószínúleg valamilyen egészségügyi probléma miatt - nem sikerült a közös gyermekvállalás, de nem kerestek orvosi segítséget, hogy kiderítsék a probléma okát. Zoltán ezt azzal indokolta, hogy „hát neki [az asszonynak] már volt egy [gyereke], így [ôt ez a kérdés] annyira nem izgatta”.

A legtöbb férfi elégedett volt korábbi, illetve jelenlegi párkapcsolatainak a minőségével. Ugyanakkor a magas iskolai végzettségűek közül néhányan a „szerelem hiányára" utaltak a gyermekvállalás potenciális akadályaként, bár az elbeszélések alapján nem igazán vált azonosíthatóvá, hogy ez pontosan mit is jelent a számukra. $\mathrm{Az} 50$ éves magas iskolai végzettségű, egyedülálló budapesti Erik például szinte kamaszos lelkesedéssel ecsetelte, hogy „a szerelem definíciójában benne van, hogy örökké együtt akartok maradni, és természetesen gyereket is akartok, ha szerelmes vagy, akarsz gyermeket a szerelmedtól”. Ugyanakkor több korábbi párkapcsolatot megtapasztalt interjúalanyunk tisztában volt azzal is, hogy a kezdeti érzelmi hevesség idővel csillapodhat, ami a tartóssá váló kapcsolatokban általában nem járt intimitáshiánnyal.

Ebben az összefüggésben némileg atipikusnak tűnhet az 52 éves magas iskolai végzettségű, vidéken élő Rómeó esete, aki számtalan, általa jól működőnek tartott 
tartós kapcsolatban élt már, azonban mégsem akart egyik partnerétől sem gyereket. Egy idő után a barátok, ismerősök - látván a jól működő kapcsolatot - érdeklődni kezdtek, hogy mikorra terveznek gyereket, Rómeó azonban elodázta a kérdést, és általában akkor vetett véget ezeknek a kapcsolatoknak, amikor a partnere is komolyabban felvetette a közös gyermekvállalás lehetőségét. Rómeó úgy értelmezte ezt, hogy ha szerelmes lett volna a partnerébe, akkor bizonyára benne sem merültek volna fel kételyek a közös gyermekvállalással kapcsolatban, így viszont azt érezte, hogy nincs értelme folytatni az aktuális kapcsolatot. Úgy tûnik, Rómeó számára a szerelem hiánya nem akadályozta meg a jól működő partnerkapcsolatok kialakulását, csak gyereket nem akart e partnerekkel együtt vállalni (ami felvetheti persze annak a lehetőségét is, hogy számára a gyermektelen kapcsolatok voltak az igazán működőképesek).

A magas iskolai végzettségú férfiak körében azért is merülhet fel a kapcsolat érzelmi oldalának a kihangsúlyozása, mert a párkapcsolati piacon előnyt élveznek: irántuk ugyanis - alacsony iskolai végzettségü társaikkal szemben - mind a magasabb, mind az alacsonyabb iskolai végzettségű nők részéről nagy a kereslet (lásd pl.: Wiik-Dommermuth 2014). Emellett mindez azt is jelezheti, hogy míg a magas iskolai végzettségú férfiak a gyermekvállalás kérdésének felvetését megelőzően nagy hangsúlyt fektetnek a kapcsolat érzelmi frissességének megtartására, addig a nők kézelfoghatóbb kritériumokhoz kötik a gyermekvállaláshoz megfelelő partner attribútumait. A nők általában a biztos anyagi háttér megléte mellett inkább azt emelik ki, hogy a partner lehetőleg megértő és következetes apa legyen, aki részt vesz a háztartási feladatokban is. E mögött az a tapasztalat is meghúzódhat, hogy a gyermekvállalás után gyakran érvényre jut a tradicionálisabb munkamegosztás: a férfiak a munkapiacon vállalnak nagyobb szerepet, míg a nőkre hárul a háztartási munkák és a gyermeknevelés jelentős része (Yavorsky et al. 2015). Mivel a férfiak Magyarországon mentesülnek a háztartási munkavégzés jelentős része alól (Takács 2008), így náluk ez a megfontolás kevésbé játszik szerepet a párválasztás és a szülőség kontextusában, ezért a praktikus megfontolások helyett a kevéssé kézzelfogható, illetve egyéni preferenciákhoz köthető jellemzők kerülhettek előtérbe.

\section{Számit-e az életkor?}

Két oka is van annak, hogy azt feltételezzük, az életkornak a férfiak körében kevésbé van jelentősége, mint a nők esetében. Egyrészt a férfiak termékenysége biológiailag kevésbé életkorhoz kötött, mint a nőké (Van Bavel et al. 2012; Beaujouan-Solaz 2013), másrészt a gyermekvállalás társadalmilag elfogadhatónak tartott életkorához köthető normák is kevésbé szigorúak a férfiak vonatkozásában. Ez azzal magyarázható, hogy a nők és a férfiak a legtöbb európai országban eltérő mértékben vesznek részt a gyermeknevelésben (Fasouliotis-Schenker 1999), s a közvélekedés szerint fontosabb, hogy egy nőnek legyen „elég ideje” felnevelni a gyermeket, mint egy férfinak. Ugyanakkor a gyermekvállalás életkori normái a nők vonatkozásában 
is sokat változtak az elmúlt évtizedekben: korábbi kutatásunk során is megmutatkozott, hogy míg az 50 évesnél idősebb nők a 30 éves kort adták meg az anyává válás felső korhatáraként, addig a kora 40-es éveikben járó interjúalanyaink még nem tekintették lezártnak saját gyermekvállalásuk kérdését (Szalma-Takács 2014). A gyermekvállalás normatívan elfogadhatónak tartott és valós életkori kitolódására más európai és hazai kutatások is felhívták a figyelmet (Testa 2006; Takács 2013; Vicsek 2018). Ezek a jelentős változások a korábban szigorúbb társadalmi normák enyhülésének és a mesterséges reprodukciós technológiák mindinkább hozzáférhetővé válásának köszönhetők.

A férfiak körében nem találtunk jelentős eltérést a gyermekvállalás még elfogadható életkorára vonatkozóan a különböző kohorszokhoz tartozó interjúalanyaink között, ami valószínúleg annak tudható be, hogy a férfiak idősebb korban is apává válhatnak. Azonban a különböző társadalmi csoportokhoz tartozó férfiak között jelentős különbségek mutatkoztak saját maguk apává válásának még elfogadhatónak tartott életkora vonatkozásában. A magas iskolai végzettségú és jobb anyagi helyzetű interjúalanyaink akár az ötvenes vagy hatvanas éveikben is el tudják képzelni, hogy gyermeket vállaljanak, míg az alacsonyabb iskolai végzettségú társaik nem vállalkoznának már arra sem, hogy 50 évesen, vagy akár a 40-es éveikben váljanak apává. Például Patrik, az egyik 50 éves, érettségivel rendelkező, városban élő, egyedülálló interjúalanyunk jövőbeli korlátozott szülői képességeivel indokolta, hogy már nem szeretne gyermeket ennyi idősen: „Azért sem akarok gyereket, mert hát 50 éves vagyok. Hova? 60 évesen, 70 évesen nem tudok utánaszaladni a diszkóba mankós bottal, hogy gyere vissza, te rohadt ribanc, mit keresel itt!" Hasonlóképpen az 55 éves, alacsony iskolai végzettségű, LAT-kapcsolatban, falun élő Endre azt állította, hogy a gyermekvállalás kérdését ó már a 40-es évei elején lezárta, hiszen ha addig nem vált apává, akkor most már túl kései lenne erre vállalkozni.

$\mathrm{Az}$ alacsonyabb iskolai végzettségűekre jellemző (ön)korlátozóbb életkori normák összefügghetnek a rossz egészségi állapottal és a férfiaknak a nőkéhez képest köztudottan alacsonyabb várható élettartamával: például 2015-ben egy magyar férfi születéskor várható élettartama (72,3 év) majdnem 7 évvel rövidebb volt, mint egy nőé (79 év) (KSH 2015). A magyar férfiak várható élettartama átlagosan 5 évvel alacsonyabb az EU-átlagnál, ami az EU-tagországok között Lettország és Litvánia után a harmadik legalacsonyabb érték (OECD 2017). Ugyanakkor, míg az általunk korábban meginterjúzott nőknek több mint az egyharmada számolt be olyan egészségügyi okról, amely megnehezítette (volna) a gyermekvállalást, addig a férfiak közül egy sem említett konkrétan ilyen egészségügyi problémát. ${ }^{8}$ Egy falun élő, alacsony iskolai végzettségű 70 éves férfinál ugyan felmerült az interjú során a gyermekvállalást akadályozó egészségügyi probléma létezése, de a témát tabuként kezelve nem beszélt erről bővebben.

8 Itt az is említendő, hogy az általunk készített szakértői interjúkban a termékenységi kérdésekre specializálódott orvosok kiemelték, hogy az utóbbi évtizedekben a férfiak terméketlensége egyre nagyobb méreteket ölt. 
Az általános rossz egészségi állapot miatt nem csak a saját gyermekvállalás nem lehetséges, de az örökbefogadás sem jelent alternatívát sok középkorú pár számára. Például az 59 éves, alacsony iskolai végzettségű, egy kisvárosban LAT-kapcsolatban élő András arról számolt be, hogy az utóbbi időben eszébe jutott az örökbefogadás, mint apává válási lehetőség (a partnere életkora nem tette lehetővé számukra a „saját" közös gyermekvállalást). Végül azonban a túl sok egészségügyi problémájuk miatt még csak meg sem említette ezt a gondolatot a partnerének, mivel úgy látta, hogy fizikailag már nem lennének képesek a szülőségre.

Legtöbb magas iskolai végzettségú interjúalanyunk azt hangsúlyozta, hogy az ő egészségi állapotuk sokkal jobb, mint a magyar átlagé, és ez lehetővé teszi számukra akár a későbbi gyermekvállalást is. Például az 51 éves, magas iskolai végzettségú, Budapesten élő, egyedülálló Dávid éppen a fizikai állapotát emelte ki, ami alkalmassá teszi őt jövőbeli szülői feladatok ellátásra: „A fizikai hátrányokat, azt még én valamennyire tudom kompenzálni, mert ugye tovább fogokélni, mint egy átlag magyar, hogyha semmi nem jön közbe, persze. De mondjuk, terveim szerint én 90 fölött fogok meghalni, és azért az egy jó, majdnem 25 évvel több, mint az átlag. Hogyha azt visszavesszük az 50-böl, akkor egy 25 éves férfi vagyok." Az 56 éves, Budapesten élő, magas iskolai végzettségủ, egyedülálló Laci szintén azt hangsúlyozta, hogy hosszú életre számíthat, amibe belefér még egy gyermek felnevelése: „Én úgy érzem, ha nem vagyok fasz, és elkezdek jobban sportolni, és leadom a hasamat, akkor mondjuk, elvagyok 80-ig. Ebbe simán belefér egy 16 éves gyerek még, velem nöhetne fel, és nyitott vagyok erre kurvára."

Szembetûnő különbség figyelhető meg abban a tekintetben is, hogy a különböző iskolai végzettségű, illetve különböző társadalmi státuszú férfiak milyen életkori maximumot adnak meg az apává válás elfogadható életkorára. Ezeket az eltéréseket a statisztikai adatok részben alátámasztják, mivel a legalacsonyabb és a legmagasabb iskolai végzettségúek között Magyarországon a legnagyobb a szakadék: alacsonyan iskolázott társaikhoz viszonyítva átlagosan 9 évvel élnek tovább a magas iskolai végzettségűek (OECD 2017). Ugyanakkor a (kora negyvenes évektől akár a hatvanas évekig terjedő) mintegy 20 évnyi eltérés az apává válás még lehetséges életkora tekintetében az alacsony és magas iskolai végzettségű férfiak között még a statisztikai adatok tükrében is túlzónak tűnhet.

\section{A gyermekvállaláshoz szükséges anyagi feltételek}

A gyermekvállalás anyagi hátterének biztosítása nem csak Magyarországon merül fel fontos kérdésként: a nemzetközi szakirodalomban is a (tervezett) gyermekvállalás előfeltételeként jelenik meg a biztos anyagi helyzet (lásd például: BrewsterRindfuss 2000; Fahlén-Oláh 2015), ami pedig erősen korrelál az iskolázottsággal. A korábbi tanulmányok azt találták, hogy az alacsony iskolai végzettségú férfiak körében magasabb a gyermektelenek aránya, mint magasabb iskolai végzettségú társaik körében (Gonzáles-Jurado-Guerrero 2006; Andersson et al. 2009; Fieder et al. 2011; Barthold et al. 2012). Ezekből az eredményekből kiindulva azt vártuk, hogy min- 
tánkban is nagy különbséget találunk az iskolai végzettség és a gyermekvállaláshoz szükséges anyagi biztonság megléte (vagy éppen hiánya) között.

A nőkkel végzett korábbi vizsgálatunkban is hangsúlyos szerepet kapott az anyagi biztonság kérdése. Ott különösen abban a vetületben merült fel, amikor arról kérdeztük őket, hogy mit gondolnak arról, ha valaki egyedülállóként vállal, nevel gyermeket. Ebben a kontextusban mindannyian utaltak a (várható) anyagi nehézségekre: bár a magasabb iskolai végzettségú interjúalanyok - a potenciális anyagi nehézségek elismerése mellett - az időhiány problémáját is kiemelték. Mindez megerősítheti azt a feltételezést, hogy Magyarországon a kétkeresős családok az életképesek, továbbá az apa hiányának összekapcsolása az anyagi biztonság hiányával arra is rávilágíthat, hogy a magyar társadalom a férfiakat tekinti elsődleges pénzkeresőnek. A férfiak válaszaiban ugyanakkor az egyedülállóként való gyermekvállalás kérdése nem kapcsolódott össze ilyen egyértelműen az anyagi források hiányával.

Míg a nyugati társadalmakban a teljes állású munkavállalás többnyire anyagi biztonságot is jelent, addig a nagyon alacsony béreknek köszönhetően Magyarországra ez nem feltétlenül jellemző: itt a kétkeresős családmodell a többség számára anyagi szükségszerűség. Ebben az alfejezetben az anyagi biztonság kérdéskörét kettébontjuk anyagi erőforrásokra (idetartozik például anyagi tartalék vagy a saját lakással való rendelkezés) és munkapiaci helyzetre. Ez a kettébontás azért is szükséges, mert Magyarországon viszonylag magas (10\% feletti) a dolgozói szegénység aránya (Eurostat 2018). Továbbá a munkapiaci helyzet vizsgálata amiatt is izgalmas kérdés, mert interjúalanyaink mindegyike aktív volt már a munkaerőpiacon, amikor az 1989-es rendszerváltás bekövetkezett.

\section{Anyagi erőforrások}

A társadalmi normák jelentős mértékben meghatározhatják, hogy milyen anyagi helyzet megléte szükséges a szülővé váláshoz (Szalma 2010). Egy olyan tradicionális társadalomban, ahol a nemi szerepek jelentősen elkülönülnek, fontos társadalmi elvárás, hogy a férfi legyen a fő kenyérkereső (Spéder 2011). A férfiakra vonatkozó szigorúbb norma az anyagi biztonság előteremtésére vonatkozóan tetten érhető abban is, hogy míg a megfelelő anyagi helyzet a nőkkel készített interjúk során csak a gyermekvállalás kérdéséhez kötődött szorosan (Szalma-Takács 2014), addig a férfiak körében már a tartós párkapcsolat kialakításánál is fontos kritériumként tűnt fel:

„Én egy ilyen bohém vagyok, az bizonyos nőknél azért egy kicsit zavaró momentum, plusz, hogy nincs egy önálló lakásom, tehát azért volt egy-két nö, akit nem akarok bántani, de azt mondanám, hogy azért nem jött velem össze, merthogy most így sarkítom, merthogy nincs lakásom" (Gellért, 54 éves, középfokú végzettségű egyedülálló, Budapest).

A lakástulajdonlás kérdése Magyarországon különösen fontos mind a tartós párkapcsolat kialakításhoz (Szalma 2010), mind a gyermekvállaláshoz (Szalma 2010; Szalma-Takács 2015), amelynek hátterében az állhat, hogy a magyarországi lakás- 
állomány 92\%-a magánkézben van (Pittini et al. 2015) és a hosszú távú lakásbérlés a legtöbb fiatal pár számára megfizethetetlen a nagyobb városokban, miközben vidéken a lakásbérleti piac többnyire hiányzik (Hegedűs-Teller 2007).

A magas iskolai végzettségű férfiak a párkapcsolat kialakításhoz és a gyermekvállaláshoz is ugyanolyan fontosnak ítélték az anyagi erőforrások meglétét, mint alacsonyabb iskolai végzettségű társaik. A magas iskolai végzettségúek azonban sokkal összetettebben írták le ezt az összefüggést, figyelembe véve, hogy ez csak egyik kritériuma a vizsgált életesemények bekövetkezésének. Például Laci, egy 56 éves, egyedülálló budapesti egyetemi tanár úgy látta, hogy a gyermekvállaláshoz ugyan elengedhetetlen a megfelelő anyagi biztonság, de az érzelemgazdag párkapcsolat is legalább ennyire fontos. Emellett kiemelte, hogy a biztos anyagi háttér nem csak a gyermekvállaláshoz szükséges, de már a párkapcsolat kialakításában is katalizátorszerepet játszhat.

A nőkhöz viszonyítva új szempont, hogy a férfiak körében nem csak a rossz anyagi helyzet, de akár a túl jó anyagi helyzet is - közvetett - akadályává válhat a gyermekvállalásnak, mivel attól tarthatnak, hogy egy esetlegesen bekövetkező válás esetén elveszíthetik a vagyont, amit az évek alatt felhalmoztak. Az 50 éves, magas iskolai végzettségü, budapesti elvált Milán például így fogalmazott: „Az én egzisztenciám az egy ilyen mintaszerü. Így a megszerzett, hogy mondjam, dolgokat bizonyos értelemben, tekintettel arra, hogy megint csak a körülöttem lévő világ tapasztalataiból kiindulva, azért óvatosan kezeltem."

Mivel Magyarországon az a bevett gyakorlat, hogy válás esetén a gyermek(ek) az anyához kerülnek, így a válást követően legtöbbször a férfiak költöznek el a közös lakásból. Ez azonban a jövőben vélhetően kevésbé lesz hangsúlyos, mivel a 2014-től hatályban lévő Ptk. Családjogi könyve szerint a bíróságok már nem rendelkezhetnek arról, hogy a gyermeket melyik szülőnél helyezik el, így az elváló szülők az eddigieknél talán nagyobb eséllyel egyezhetnek meg a szülői felügyelet közös gyakorlásában (Náday 2014), ami pedig azzal járhat, hogy válás esetén egyik fél sem veszítheti el a közösen megszerzett lakáshasználatot a gyermek érdekére hivatkozva. Ezáltal csökkentheti a gyermekvállalás lehetséges anyagi kockázatát az egzisztenciálisan jobb anyagi helyzetűek körében, illetve a gyermeknevelés költségei is igazságosabban lehetnek elosztva a két szülő között ezen intézmény érvényesülése esetén.

\section{A rendszerváltás hatása a munkapiaci aktivitásra és a gyermek-(nem)vállalásra}

A standardizált életpályák kialakulása a család és a munka tekintetében az 1960-as évekig vezethető vissza a nyugati társadalmakban, amikor a legtöbb ember lényegében ugyanazt a pályát járta be ugyanabban a sorrendben: kijárta az iskolát, majd dolgozott, és végül nyugdíjba ment (Kohli 1986; Riley et al. 1994). Az 1960-as évek végétól mind a foglalkozási, mind a családi életutak pluralizálódásának hatására (Widmer- 
Ritschard 2009) a domináns életút fokozatosan kiegészült néhány lehetséges alternatívával, gyakran a nemekre jellemző eltérésékkel: a fiatalok egy része például előnyben részesítette a továbbtanulást annak érdekében, hogy elkerülje a munkanélküliséget, és ezzel párhuzamosan első tartós párkapcsolatként az élettársi kapcsolatot választották a házasság helyett, s ezzel párhuzamosan - ideiglenesen vagy esetleg véglegesen elhalasztották a gyermekvállalást is. Ugyanakkor az államszocialista társadalmakban az 1960-as években nem következett be az életutak pluralizálódása, és a szabványosított életutak dominanciája egészen a rendszerváltásig fennmaradt, amikor is gyors destandardizáció kezdődött meg. Ez a hirtelen változás főként a gazdaság átstrukturálódásának köszönhetően jött létre, ami gyakran kényszerpályára taszította az aktív korú munkavállalókat: mindez hatott a családi gyakorlatokra is. Spéder és Kapitány (2014) például arra hívták fel a figyelmet, hogy az általuk vizsgált közép- és kelet-európai országokban, Magyarországon, Bulgáriában és Grúziában, a tervezett gyerekek a nyugat-európai országokhoz képest kisebb arányban születnek meg. Az elmaradt gyerekvállalást azokkal a rendszerváltáshoz köthető nagyarányú és gyorsan lezajlott strukturális és kulturális változásokkal magyarázták, melyek miatt a gyermekvállalás elhalasztása tűnt racionális döntésnek.

Az általunk vizsgált kohorszhoz tartozók mindegyike szembesült a rendszerváltozás hatásaival a munkapiacon: interjúalanyaink közül mindenki beszámolt arról, hogy a rendszerváltozás valamilyen formában érintette a munkapiaci tevékenységüket. A legtöbben negatív hatásról számoltak be: az 1990-es évek elején megtört munkapiaci karrierjük miatt jó páran pályamódosításra kényszerültek, mások pedig munkanélkülivé vagy rokkantnyugdíjassá váltak.

A 60 éves, alacsony iskolai végzettségű, falun élő, egyedülálló Feri a következőképpen emlékszik erre az időszakra: „Elmentem az [X] vállalathoz. Nagyon sok pénzt nem kerestünk ott sem, de legalább volt szabadidő [amit arra hasznositott, hogy a második gazdaságban aktivan dolgozhasson]. 1987 táján aztán begyütt ez a privatizálás. Akkor már látszott, hogy leépítések voltak, csökkent a létszám. Azt mondom, akkor hagyjuk itt a fenébe ezt is, mert előbb-utóbb ott kő hagyni. Akkor lettem őstermelő. Azt folyamatosan 96-ig, azt akkor ilyen vérnyomás miatt összevissza voltam, azt akkor leszázalékoltak." $\mathrm{Az} 50$ éves, budapesti, magas iskolai végzettségú, egyedülálló Erik még fiatal volt a rendszerváltás idején, és bár konkrét hátrány nem érte, de ő is érzékelte, hogy más keretek között kellett mozognia, mint az azt megelőző időszakban: „...bár mi akkor pályakezdők voltunk, és nyilván azoknak volt igazán nehéz, akik inkább a pályájuk utolsó szakaszában voltak. De hát világosan látszott, hogy teljesen megváltoztak a feltételek, és a talpon maradáshoz nagyon-nagyon keményen oda kell az embernek tennie magát, mert máskülönben azért nem olyan egyszerü ez”.

A rendszerváltozás nemcsak munkanélküliséggel és keményebb munkarenddel járt együtt, de felszámolta a korábban megszokott kiszámíthatóságot, és egyfajta máig tartó állandó bizonytalanságot teremtett, ahogy erről a következő két magas iskolai végzettségű, Budapesten élő interjúalanyunk is beszámolt: 
„Nem tudjuk, hogy mi lesz két, három, öt, tíz év múlva, mert nem tudjuk, hogy hogyan alakulnak a dolgok, de én remélem, hogy ezt [az életmódot] sikerül többé-kevésbé fenntartani. Garanciák nincsenek rá, mert a folyamatok azok, a nagy folyamatok kiszámíthatósága erösen lecsökkent” (Elek, 52 éves, elvált).

„Hála istennek, volt annyi tartalékom, hogy kibekkeljem az első időket, inkább ez egy ilyen búvópatakként müködō, ilyen tompa fenyegetettségnek az érzése. Tehát hogy nem volt olyan, hogy jaj, istenem, most hova költözzek vagy mit egyek, de olyan, hogy feketén láttam a jövőt, olyan volt" (Ödön, 62 éves, egyedülálló).

Mindezek a változások nem csak a munkapiaci karrierre lehettek hatással, de dominóeffektusként hathattak a családi életre is: mind a tartós párkapcsolatok kialakítására, mind a szülővé válásra (Hagestad-Call 2007). A munkapiacon tapasztalt bizonytalanságok megnehezítették a hosszú távú tervezést, a gyermekvállalás pedig egy hosszú távú elköteleződést jelent, ezért ezek a folyamatok a gyermekvállalás tervezett életkorának kitolódásához vagy éppen végleges elhalasztásához is erősen hozzájárulhattak.

\section{Gondozási feladatok ellátása mint a gyermekvállalás akadálya}

A gyermektelen nők körében végzett kutatásunk rávilágított arra, hogy a saját gyermek hiánya nem feltétlenül jelent „gyermek- és gondozásmentes” életformát: sőt interjúalanyaink egy része számára közvetetten vagy közvetlenül éppen valamilyen általuk ellátott gondozási feladat akadályozta a saját gyermekvállalást (Szalma-Takács 2014). A megkérdezett gyermektelen férfiak körében is számos olyan esettel találkoztunk, ahol az interjúalany idősebb közeli rokona (többnyire az egyik vagy mindkét szülő, esetleg nagyszülő) gondozásában vállalt szerepet életének egyik, általában több éven át tartó, szakaszában. Néhányan közülük együtt is éltek a gondozottal (többnyire az anyjukkal). Az együttélést leggyakrabban azzal magyaráztak, hogy - érzelmi és/vagy anyagi okok miatt - el szerették volna kerülni, hogy intézménybe kerüljön a családtag.

Interjúalanyaink majdnem harmada (pontosan kilencen) élt együtt legalább egy idősebb családtagjával, s közülük heten gondozási feladatokat is elláttak. Az 50 éves, középfokú végzettségű, budapesti, egyedülálló Norbert például úgy vélte, hogy gondozási tevékenysége hozzájárulhatott ahhoz, hogy elriadt a gyermekvállalástól: „... ebben például lehet, hogy benne van ez a nagymamasztori is. Tehát hogy sok ilyen szenvedést láttam, és hogy nagyon félek attól, hogy valaki szenved. Tehát hogy tudtam, hogy ez [a gyerekvállalás] nekem ilyen állandó napi iszonyú mennyiségú szorongást okozna, tehát ha nincs ott az a gyerek, vagy ha ott is van, hogy beteg-e, hogy mi lesz".

$\mathrm{Az}$ általunk vizsgált gyermektelen nők tapasztalataihoz hasonlóan a férfiaknál legtöbb esetben a gondozási tevékenység nem csak a gyermekvállalást akadályozta meg, de - talán még nagyobb mértékben, mint ahogy ezt a nőknél találtuk - a partnerkapcsolat kialakítását is meghiúsította. Ez azzal is magyarázható, hogy a gondozási tevékenység jobban kapcsolódik a női, mint a férfi szerepkörhöz Magyaror- 
szágon, egy törődésdeficittel és tradicionális otthoni munkamegosztással egyaránt jellemezhető társadalomban. Ezáltal a férfiakat, akik aktív részt vállalnak idősebb rokonaik ápolásában, esetleg kevésbé tekintik férfiasnak, s emellett egy ilyen feladatot végző férfival azért is lehet kevésbé vonzó a tartós párkapcsolat kialakítása, mert fennáll annak a veszélye a női partner számára, hogy az ápolási teendők könnyen az ő feladatkörébe csúszhatnak át a párkapcsolat stabillá válása esetén. Az 52 éves gimnáziumi végzettségű, budapesti egyedülálló Arnold például a következő feszültséggel terhelten látja a helyzetét: „Szeretném, hogy az anyukám minél tovább éljen, de hát tudja, hogy akkor ennek az a hátránya, hogy addig nem tudom megoldani [partnerkapcsolat kialakitását], mert nem tudom, lehet, hogy egyszer találkozok valakivel, aki szimpatikus lesz... de [az anyámat] semmiképpen nem adnám otthonba. Annyit nyújtott nekem az életem során az anyám, hogy ezt nem tudom elképzelni, hogy az öregek otthonába tegyem."

Női interjúalanyaink között találkoztunk olyan esettel, amikor a faluban élő szülők megakadályozták, hogy velük élő legkisebb lányuk tartós partnerkapcsolatot alakítson ki, nem azért, mert azonnal szükségük lett volna gondozási segítségére, hanem mert biztosítani akarták saját maguk számára, hogy a jövőben legyen mellettük valaki, aki gondozza őket, ha erre majd rászorulnak. Hasonló eset előfordult a gyermektelen férfiak körében is egy olyan falun élő család esetében, ahol csak fiúgyermekek voltak. Itt a szülők nem engedték meg a legkisebb fiú számára, hogy barátnőt vigyen a házhoz. A 60 éves, alacsony iskolai végzettségű Feri nem rendelkezett kellő anyagi forrással ahhoz, hogy elköltözzön otthonról, így a szüleivel kellett élnie, és nem alakíthatott ki tartós párkapcsolatot a szülei haláláig. Feri ezt a fajta hozzáállást szülei szigorával és konzervatív nézeteivel indokolta: ...anyám nagyon szigorú volt, hogy' is mondják, ő még ilyen fatengelyes volt”. Amikor meghaltak a szülei, Feri már 45 éves volt; ekkorra a korban hozzá illő nők már férjnél voltak vagy elváltak, megözvegyültek, ezért egy nála idősebb elvált nővel alakította ki élete első tartós párkapcsolatát, akivel saját gyermek vállalását tervezni már nem lett volna reális elvárás.

$\mathrm{Az} 54$ éves, magas iskolai végzettségű, budapesti egyedülálló Tamás hasonló élethelyzetről számol be, bár - legalábbis utólag - némileg kritikusabban látja a helyzetet: „...anyám abban bünös, hogy nekem nincs családom és gyerekeim, abban ő valamennyire hibás. Mert ô megtehette volna azt, hogy mindenféle módon kommunikálja felém, hogy nyugodtan hagyjam ôt egyedül. De nem tette meg. És ugye én meg érzelmileg már eleve egy olyan helyzetben voltam, hogy az apám után nekem egy ilyen szamaritánus szerepem lett az anyámmal szemben”. Feri esetéhez képest azonban két jelentős különbség is felfedezhető Tamás történetében. Az egyik, hogy míg a családjával együtt rossz anyagi körülmények között élő Feri aktív tiltással találta magát szemben, addig a magas társadalmi helyzetű családból származó Tamás maga hozta meg azt a döntést, hogy nem hagyja egyedül a beteg anyját. A másik különbség, hogy a magasabb iskolai végzettségű Tamás önreflektívebb módon közelítette meg a helyzetet, és a saját érzelmi állapotára is utalt, ami gúzsba kötötte. A végeredmény azonban hasonló 
a két férfi esetében: a szülők haláláig nem tudtak kialakítani tartós párkapcsolatot, ami hozzájárult ahhoz is, hogy nem született gyermekük.

\section{Férfispecifikus új tényezök a gyermektelenség hátterében}

Néhány új elem is megjelent a férfiak gyermektelenségéhez köthetően, amelyek a nőkkel végzett kutatásunk során kevésbé váltak hangsúlyossá, illetve egyes elemeket ott egyáltalán nem figyelhettünk meg (Szalma-Takács 2014). Ebben az alfejezetben ezeket fogjuk áttekinteni.

\section{Tudatos gyermektelenség}

A tudatos gyermektelenség nagyon marginális jelenség Magyarországon: legalábbis a legtöbb válaszadó - férfiak és nők egyaránt - megkérdezésükkor arról számol be, hogy szeretne gyermeket vállalni valamikor az élete során - ez derült ki az Életünk Fordulópontjai első, második és harmadik hullámának paneladatain végzett korábbi elemzésünkből is (Szalma-Takács 2012, 2015, 2018). Ugyanennek az elemzésnek az eredményei arra is rámutattak, hogy jellemzően azok sem tudták megvalósítani gyermekvállalási terveiket, akik átmeneti állapotként tekintettek saját gyermektelenségükre. Ugyanakkor felmerül az a módszertani kérdés, hogy vajon kvantitatív módszerekkel megfelelően lehet-e vizsgálni egy olyan érzékeny témát, mint a tudatos gyermektelenség egy olyan társadalomban, ahol erős kényszerítő normák írják elő szinte mindenki számára a gyermekvállalást. A nők körében végzett interjús vizsgálataink során fény derült arra, hogy létezik egy nagyon szúk - kizárólag magas iskolai végzettségű - kisebbség, akik tudatosan nem vállaltak gyermeket, vagy legalábbis tudatosan alakították úgy az életüket, hogy elkerüljék az esetleges gyermekvállalást (például megszakították a párkapcsolatukat azzal a partnerrel, aki mindenképpen szeretett volna gyermeket), s erről beszámolni is hajlandóak (Szalma-Takács 2018).

Az általunk vizsgált gyermektelen férfiak esetében három fő különbséget találtunk a nőkhöz képest a tudatos gyermektelenség tekintetében. Egyrészt a női mintával összevetve nagyobb arányban számoltak be férfi interjúalanyaink arról, hogy tudatosan nem kívánnak gyermeket vállalni: a mintába került 25 gyermektelen nőből mindössze hárman, míg a 30 gyermektelen férfi közül tizenketten tudatosan nem szerettek volna gyermeket (Szalma-Takács 2018). A tudatos gyermektelenség spektruma e tizenkét férfinál elég változatos jelenségeket fedett le: volt köztük olyan, aki annyira biztosan nem szeretett volna gyereket, hogy önköltségen részt vett az ondóvezetékek átvágásával járó vazektómiabeavatkozáson. Másoknál a tudatos gyermektelenség passzívabb formában mutatkozott meg: például annak hangsúlyozásával, hogy ő valóban nem szeretne gyereket, de ha esetleg mégis úgy alakulna, hogy valami úton-módon gyermeke születne, azért felnevelné.

Másrészt sokkal szabadabban beszéltek a tudatos gyermektelenségükrôl, mint a nők: azt sugallva ezzel, hogy rájuk kevésbé hat a (kötelező) gyermekvállalást norma- 
tívan előíró társadalmi nyomás. Vagyis az általunk tapasztalt különbségek a tudatosan választott gyermektelenséget felvállaló nők és férfiak arányában nem feltétlenül jelentik azt, hogy a nőkhöz képest több férfi lenne, aki nem szeretne gyermeket. Mindez összefügghet azzal is, amit már korábban is hangsúlyoztunk: a szülői gondoskodás Magyarországon erősen a nőkhöz köthető szerepként jelenik meg, és a közvélekedés szerint egy nő nem élhet teljes életet gyermek nélkül, míg a férfiakkal szemben mintha kevésbé szigorúak lennének az ilyen típusú elvárások (Szalma 2014). A normatív elvárásokkal való megküzdés oly módon is megjelent az interjúkban, hogy a tudatosan gyermektelen férfiak szinte „sikerként” beszéltek arról, hogy nem született gyermekük: azaz sikerült „leküzdeniük” az apává válás normáját egy tradicionális és pronatalista társadalomban. Az 50 éves, magas iskolai végzettségú, egyedülálló, kisvárosban élő Kálmán például elmondta, hogy bár szereti a gyerekek társaságát, de ez a szeretet soha nem kulminálódott abban, hogy saját gyerekre vágyott volna. Egy másik magas iskolai végzettségú interjúalanyunk, a budapesti 53 éves elvált Zsigmond úgy fogalmazott, hogy nem mindenkinek az a küldetése, hogy gyermeke legyen: „Nincs olyan érzésem, hogy valami kimaradt volna az életemből, mert nekem nincs gyerekem." De olyan, szinte harcosan gyermektelen interjúalany is akadt a férfiak között, aki nemcsak hogy nem vágyott soha gyermekre, de kifejezetten irtózott a gyerekek társaságától: „...olyan [partnerem] igazából sose volt, aki rá akart volna engem beszélni a gyerekvállalásra, mert az annyira nyilvánvaló volt, hogy én irtózom tôlük, teljes képtelenség, szóval ez olyan, mint hogy [... ha] valaki meggyooződésből vegetáriánus, akkor normális ember nem erôlteti a húsevést" (Elek, 52 éves, magas iskolai végzettségü, elvált, Budapest).

Végül az is új fejlemény volt a gyermektelen nőkhöz képest, hogy a férfiaknál találkoztunk tudatosan gyermektelenekkel az alacsonyabb iskolai végzettségúek körében is, bár az érzékelhető volt, hogy ők a gyermek nem vállalás tudatosságát kevésbé meggyőzően artikulálták a magas iskolai végzettségű társaikhoz képest. Például egyikük, az 55 éves, alacsony iskolai végzettségű, LAT-kapcsolatban falun élő Tibor nem indokolta meg, mi áll annak a hátterében, hogy nem szándékozott gyermeket vállalni, csupán azt mondta, hogy „Különösebb szándékkal nem akartam gyereket.", vagyis nem tervezte, hogy gyermeke szülessen, de ha úgy alakult volna, hogy lesz neki, azt sem bánta volna. A 62 éves, alacsony iskolai végzettségű, falun élő egyedülálló Márton hasonlóan vélekedett arról, hogy nem született gyermeke: „Ha újrakezdhetném az életem, szerintem nem hoznék más döntést. A gyermekvállas szempontjából sem hoznék más döntést." - Az alacsony iskolai végzettségű férfiak a tudatos gyermektelenségről egyrészt azért beszélhetnek szúkszavúbban, mert önreflexivitásuk és nyelvi kifejezőkészségük iskolázottabb társaikhoz képest korlátozottabb lehet. Másrészt, náluk talán nagyobb valószínűséggel fordulhat elő, hogy bár szerettek volna gyermeket, de a megfelelő partnerkapcsolat vagy a biztos anyagi háttér hiánya miatt meghiúsuló gyermekvállalásukat (Trimarchi-Van Bavel 2017) utólag értékelik át úgy, hogy tudatosan nem szerettek volna gyermeket vállalni. 


\section{Függőségek}

A függőségek, pontosabban az alkoholizmus témaköre a nőkkel készített interjúkban is megjelent: általában azzal összefüggésben, hogy az interjúalany gyermekkorában azért nem élt boldog családi életet, mert valamelyik vagy akár mindkét szülő alkoholproblémával küzdött; illetve többen arról is beszámoltak, hogy alkoholproblémával küzdő partnerükkel tönkrement a párkapcsolatuk (Szalma-Takács 2014). Férfi interjúalanyaink közül hárman azonban maguk is függőségekkel küzdöttek az életük egy bizonyos szakaszában, ami - saját elmondásuk szerint - hatással volt arra, hogy később nem született gyermekük. A függőség témaköre azonban több más interjúalany elbeszélésében is megjelent a gyermektelen férfiakkal szemben élő negatív előítéletekkel összefüggésben: ők arról számoltak be, hogy ha egy bizonyos életkor felett egy férfinak nincs gyermeke, akkor esetleg azt gondolhatják róla, hogy impotens, meleg vagy drogfüggő.

$\mathrm{Az} 55$ éves, alacsony iskolai végzettségű, vidéki városban LAT-kapcsolatban élő Endre bevallása szerint a húszas éveiben 10 évig volt alkoholista, és ez szerinte nagymértékben közrejátszott abban, hogy ebben az időszakban nem tudott tartós párkapcsolatot kialakítani és ezért gyermeke sem született: „Ott löttem el az egészet. Be is ismerem: [a munkavállalásban] az első tíz évemet azt totál [részegen töltöttem], de úgy, hogy nem józanodtam ki." Egy másik interjúalanyunk, az 54 éves, középfokú végzettségű, egyedülálló, budapesti Gellért azonban nem tartotta magát alkoholistának, habár párkapcsolatai során gyakran találkozott, találkozik azzal, hogy alkoholfogyasztása konfliktust okoz. Előfordult, hogy párkapcsolatának is ez vetett véget: „Tehát ha elmentünk este szórakozni, elmentünk egy koncertre vagy egy kávéházba, akkor is megjegyzést tett rá. De ilyen beszélgetés nem volt, hogy ő azt mondja, hogy figyelj, te alkoholista vagy, és én csak akkor járok veled, ha egyáltalán nem iszol... És egy hét múlva meg közölte velem a Facebookon, még csak nem is telefonon, hogy találkozhatunk, de csak mint barátok." - Látható, hogy míg Endre saját magát írta le alkoholistaként, addig Gellértet a partnerei definiálták függőnek. Valószínűsíthető, hogy Gellért kevésbé vagy társadalmilag inkább elfogadott módon alkoholista: így sikerült neki párkapcsolatokat kialakítani, melyek csak azután értek véget, mikorra partnerei jobban megismerték ôt. Endrénél azonban az alkoholizmus szintje már a párkapcsolat kialakítását is megakadályozta.

A mintánkba bekerült egy olyan interjúalany is, aki éveken át bevallottan kábítószerfüggő volt. Az 50 éves, középiskolai végzettségű, vidéki városban élő, egyedülálló Patrik arról számolt be, hogy a kábítószer megváltoztatta azt, hogy miként szemléli a világot. Az első leszokása után pár évig „tiszta” maradt, és ebben az időszakban próbált úgy élni, amit az emberek többsége „normális” életnek tekint: „Elhittem, hogy az ember akkor lesz boldog, ha keményen dolgozik, van egy szép háza és vannak gyerekei. Keményen dolgoztam, volt egy szép házam, de azt éreztem, hogy egy droid vagyok. Éveket töltöttem szerhasználat nélkül, de boldogtalanul, és 2000-ben visszaestem, és akkor 3 év alatt eldrogoztam két boltot, egy Mercedest meg egy V. kerületi luxuslakást.” Patriknak 
végül sikerült leszoknia a kábítószerről, de akkorra már az új életébe nem fért bele a gyermekvállas, mivel túl idősnek tartotta magát ahhoz, hogy apává váljon.

Az alkohol- és drogproblémák nemcsak közvetlenül az intenzív függőség időszakában akadályozhatják meg a gyermekvállalást, hanem a leszokás utáni időszakra is negatív hatással lehetnek. Érintett interjúalanyaink úgy látták, hogy elpocsékolták a függőséggel töltött éveket, melyek gyakran egybeestek azzal az időszakkal, ami az általuk érzékelt társadalmi elvárások szerint - és saját vélekedésük szerint egyaránt - a családalapítás időszaka lehetett volna. A statisztikák is felhívják a figyelmet e téma fontosságára: Magyarországon kétszer többen halnak meg alkohollal összefüggô problémák miatt, mint az EU15 országaiban, továbbá jelentős nemek szerinti eltérés is megfigyelhető: a nők 1,4\%-a, a férfiaknak viszont $10 \%$-a volt nagyivó ${ }^{9}$ 2014-ben Magyarországon (Egészségjelentés 2017).

\section{Konklúzió}

Ebben a tanulmányban arra fókuszáltunk, hogy milyen tényezők húzódhatnak meg a - legalább 50 éves - magyar férfiak gyermektelensége mögött, valamint a korábbi kutatási eredményekkel összevetve azt is áttekintettük, hogy milyen hasonlóságok és különbségek figyelhetők meg az általunk vizsgált gyermektelen nők és férfiak jellemzői között. A tanulmány első felében azokat a lehetséges okokat vettük közelebbről szemügyre, melyek a korábbi kutatásaink tükrében (Szalma-Takács 2014, 2018) a nők körében fontosnak mutatkoztak: idetartozott a párkapcsolat hiánya vagy annak rossz minősége, az életkori korlátok, az egészségi állapot, a kedvezőtlen anyagi (és munkapiaci) helyzet, valamint a közeli családtag ápolásával kapcsolatos feladatok ellátása. Bár mindezek a tényezők szerepet játszottak a gyermek-(nem) vállaláshoz vezető döntésekben a férfiak körében is, de eltérő mértékben és némileg eltérő módon, mint ahogy a nők körében ezt korábban megfigyelhettük.

Míg a nőknél a partnerkapcsolat hiánya és annak rossz minősége tűnt a gyermektelenséget meghatározó legfontosabb tényezőnek, addig a férfiaknál ez kevésbé hangsúlyos szerepet kapott. A férfiakkal készített interjúk során kiderült, hogy körükben ritkábban fordult elő, hogy valaki egyetlen tartós párkapcsolatot sem tudott kialakítani az élete folyamán. Így az életút-megközelítés nem igazolta, hogy a férfiaknál a partnerkapcsolat hiánya lenne gyermektelenségük egyik vagy akár fő meghatározó tényezője. Emellett a párkapcsolatban élő férfiak a kapcsolataik minőségével is elégedettebbeknek mutatkoztak, mint női interjúalanyaink. Róluk tehát nem mondható el, hogy partnerkapcsolatuk nem megfelelő minősége miatt nem szerettek volna gyermeket vállalni. Esetükben inkább a női partnernek - a fer-

9 A nagyívó definícióját az idézett jelentés a következőképpen határozta meg: az egészséget károsító mértékben alkoholt fogyasztók tekinthetők nagyivóknak. Nemek szerinti bontásban: „azokat a nőket, akik a kérdezést megelőző héten összesen több mint 7, azokat a férfiakat, akik több mint 14 egységnyi alkoholt fogyasztottak, illetve azokat, akik egy alkalommal 6 vagy annál több italt fogyasztottak" (Egészségjelentés 2017: 75). Egy alkoholegység egy korsó sörnek, 2 dl bornak vagy 0,5 dl röviditalnak felel meg. 
tilitási életkort meghaladó - idősebb életkora játszhatott közre a gyermekvállalás meghiúsulásában: előfordult, hogy az idősebb női partnernek biológiailag már nem lehetett gyermeke, illetve az is, hogy a partnernek már volt(ak) gyermeke(i), és nem szeretett volna több gyermeket vállalni.

Továbbá míg a nők jól körülhatárolható - anyagi és törődési - attribútumok mentén alakították ki a gyermekvállaláshoz megfelelő partner képét, addig például a magas iskolai végzettségú férfiakra a párkapcsolat érzelmi oldalának kidomborítása, a szerelem fontosságának a hangsúlyozása volt a jellemző. Ez valószínúleg öszszefüggésbe hozható azzal, hogy a magas iskolai végzettségú, illetve magasabb társadalmi pozíciójú férfiak iránt túlkereslet mutatkozik a párkapcsolati piacon, ahol így ők nagyobb eséllyel kereshetnek másik partnert, ha netán nem találnák eléggé érzelemgazdagnak aktuális kapcsolatukat.

A gyermekvállaláshoz szükséges anyagi feltételeket két dimenzió - az anyagi erőforrások és a munkapiaci helyzet - mentén vizsgáltuk. Erre azért volt szükség, mert Magyarországon gyakran a stabil munkapiaci helyzettel rendelkezők is csupán szűkös anyagi erőforrásokkal rendelkeznek. Interjúink azt mutatták, hogy az anyagi tényezők is eltérő mechanizmusokon keresztül vezethetnek gyermektelenséghez a férfiak és a nők esetében. A nőknél a bizonytalan munkapiaci helyzet és a rossz anyagi körülmények közvetlenül a gyermekvállalást akadályozzák meg: például azáltal, hogy visszatartják azokat a nőket, akik nem találtak megfelelő partnert, attól, hogy akár egyedül is belevágjanak a gyermekvállalásba. A férfiaknál ezek a tényezők már a partnerkapcsolat kialakítását - s ezáltal közvetve a szülővé válást - is megnehezíthették. Mindez egybevág azokkal a Magyarországon uralkodó tradicionális elvárásokkal, melyek szerint elsősorban a férfiaknak kell a családfenntartó szerepet ellátniuk: ha egy férfi nem rendelkezik biztos anyagi háttérrel (stabil foglalkoztatási helyzettel, lakástulajdonnal), akkor kevésbé keresett a párkapcsolati piacon, mint gazdagabb erőforrásokkal rendelkező társai. Ugyanakkor a férfiak körében a túl jó anyagi helyzet is nehezítheti a partnerkapcsolat kialakítását, s ezáltal a gyermekvállalást: érintett interjúalanyaink szerint ugyanis ilyen helyzetben attól lehet tartani, hogy egy esetleges válás következtében elveszíthetik felhalmozott vagyonukat.

A közeli családtag gondozása szintén eltérő módon játszhat szerepet abban, (a)hogy a férfiak és a nők nem vállaltak gyermeket. Míg női interjúalanyaink esetében a gondozási feladatok végzése nem a párkapcsolatok kialakítását, hanem közvetlenül a gyermekvállalást akadályozta (hiszen egy idős vagy tartósan beteg ember ápolása és a gyermeknevelés egyszerre túl nagy - időbeli és fizikai - megterhelést jelenthet a nők számára egy olyan társadalomban, ahol az intézményi ellátás szerepe minimálisnak mondható, és mindezek a feladatok szinte kizárólag a nőkre hárulnak), addig a férfiaknál az idős rokon ápolása már a párkapcsolat kialakítását is megnehezíthette. Mivel a szúkös anyagi források és a szigorú társadalmi normák miatt az ápolás gyakran azzal járt, hogy az érintett férfiaknak egy háztartásban kellett élniük az ápolásra szoruló közeli rokonnal (gyakran anyjukkal vagy nagyanyjukkal), 
így már a párkapcsolat kialakítása is nehézzé vált, elsősorban a privát szféra hiánya miatt. Ezekben az esetekben az ápolási feladat a párkapcsolat kialakításának akadályozásán keresztül közvetett módon vált a gyermekvállalás akadályává.

Tanulmányunk második felében azt mutattuk be, hogy milyen új „férfispecifikus” gyermektelenségi tényezőkre bukkantunk interjúinkban, amelyek a női interjúkban nem tû́ntek fel, vagy csak kisebb szerepet játszottak. Az egyik ilyen újdonság az volt, hogy a férfiak körében sokkal markánsabban jelent meg a tudatos gyermektelenség felvállalása, mint a nőknél: például nem csak magas iskolai végzettségűek fogalmazták meg, hogy nem szeretnének, illetve soha nem is szerettek volna gyermeket vállalni, hanem a kevésbé iskolázott férfiak körében is találkoztunk olyanokkal, akik szándékosan választották a - Gillespie (2003) szóhasználatával élve - „gyermekmentes" életet. Ez nem feltétlenül jelenti azt, hogy több férfi lenne, mint nő, aki tudatosan választja a gyermektelenséget: lehetséges, hogy ez a különbség abból fakad, hogy a férfiak a nőkhöz képest szabadabban felvállalhatják az ezzel kapcsolatos véleményüket (például mert úgy vélik, hogy a nőinél kevésbé stigmatizált a férfi gyermektelenség) - nem csak egy survey vizsgálat keretében, de egy interjús vizsgálat során is.

A másik újdonság a női gyermektelenséghez képest, hogy férfi interjúalanyaink esetében előfordult, hogy a gyermekvállalás elmaradásához közvetett vagy közvetlen módon hozzájárult valamilyen szerhasználathoz kapcsolódó saját függőség. Az érintett interjúalanyok leginkább múltbéli alkohol- vagy droghasználati problémák máig ható, családalapítást akadályozó következményeiről számoltak be.

Jelen írásunk úttörő jellegú abban a tekintetben, hogy Magyarországon kvalitatív módszerekkel korábban a férfiak gyermektelenségét még senki nem vizsgálta. Bízunk benne, hogy sikerült felhívnunk a figyelmet arra, hogy gyakran eltérő okok állhatnak a férfi és a női gyermektelenség hátterében, illetve hasonló okok is eltérő mechanizmusokon keresztül vezethetnek a gyermektelenség fennmaradásához vagy fenntartásához. Társadalmi szinten azért érdemes ezekre az okokra odafigyelni, mert Magyarországon a tudatosan választott „gyermekmentes” életforma kevésbé elterjedt, mint például a német ajkú társadalmakban (Svájcban, Németországban vagy Ausztriában), így fontos megérteni, hogy milyen tényezők akadályozhatják a szülővé válást.

A nemek szerinti különbségek rávilágítanak arra, hogy a férfiak esetében elsődleges a biztos anyagi helyzet megteremtése (beleértve a saját lakástulajdon meglétét) ahhoz, hogy a gyermekvállaláshoz szükséges stabil párkapcsolatot ki tudják alakítani. Ennek eléréséhez a munkapiaci bizonytalanságok elleni védelem növelésére lenne szükség (például hosszabb ideig és magasabb szinten biztosított ellátások az esetlegesen a munkából való kiesés - betegség vagy munkanélküliség - időszakára). Továbbá az is kedvezően hatna a gyermekvállalásra, ha a társadalmi normák elmozdulnának a hagyományosnak tekinthető nemiszerep-elvárásoktól a kiegyenlítettebb munkamegosztás felé: a nők és a férfiak kiegyensúlyozottabb módon ven- 
nének részt a család anyagi hátterének megteremtésében, valamint a háztartási és a gyermeknevelési feladatokban is. Emellett pedig szükséges és egyre inkább fontos lesz az olyan idősödő társadalmakban, mint Magyarország, hogy az állam valódi támogatást nyújtson az idősek és rászorulók otthoni ápolásához, különösen abban az esetben, ha ehhez gyermekgondozási feladatok is járulnak, mivel az idős- illetve betegápolás és a gyermekgondozás nehezen összeegyezethető feladatok. Ebben az esetben számíthatnánk arra, hogy a (nem tudatos választás eredményeként) gyermektelen nők és férfiak elől elhárulna a gyermekvállalást jelenleg akadályozó tényezők jelentős része.

A gyermektelenséghez köthető számos kérdést nem tudtunk - kellő mélységben - tárgyalni jelen tanulmányunkban, de reményeink szerint sikerült felkelteni a figyelmet a vizsgált témakör iránt, és ezáltal arra ösztönözni kollégáinkat, hogy folytassák e terület vizsgálatát. Érdemes lenne például megvizsgálni, milyen a férfiak attitűdje és tapasztalata azzal kapcsolatban, hogy egyedül vállalnak gyermeket (akár örökbefogadás útján), vagy többet foglalkozni az általunk társadalmilag előírt gyermektelenségnek nevezett kategóriával. Szintén érdeklődésre tarthatna számot annak az elemzése, hogy miként tekintenek a férfiak azokra a gyerekekre, akikkel egy háztartásban élnek, de nem vér szerinti gyermekük - hiszen a férfiaknál nagyobb arányban fordulhat elő, hogy életük egy-egy szakaszában ideiglenesen apaszerepbe kerülnek partnerük gyermekeivel. Ebből a szempontból a férfiak gyermektelensége - ahogy tanulmányunkból kiderült - még inkább képlékeny jelenség, mint a nőké: nem csak biológiai, de társadalmi okokra visszavezethetően is.

\footnotetext{
Abstract: In this paper we examine the factors, which can contribute to men's childlessness in contemporary Hungary. We also try to answer the question whether different childlessness patterns can be observed among men and women in Hungary. This study is the continuation of our previous research conducted among childless women, which we now extend with a focus on male childlessness.

The empirical base of this paper includes 30 qualitative interviews conducted with childless men between 2015 and 2016 in different types of settlements in Hungary. According to our findings different factors can lead to male and female childlessness, or in some cases the same factors can influence male and female childlessness via differing mechanisms.
}

Keywords: childlessness, men, qualitative analysis, comparison with patterns of female childlessness, Hungary

\section{Irodalom}

Andersson, G. - Knudsen, L. - Neyer, G. - Teschner, K. - Ronsen, M. - Lappegård, T. - Skrede, K. - Vikat, A. (2009): Cohort fertility patterns in the Nordic countries. Demographic Research, 20(14): 313-352.

Barthold, J. - Myrskylä, M. - Owen, R. J. (2012): Childlessness drives the sex difference in the association between income and reproductive success of modern Europeans. Evolution and Human Behavior, 33(6): 628-638. 
Beaujouan, É. - Solaz A. (2013): Racing against the biological clock? Childbearing and sterility among men and women in second unions in France. European Journal of Population, 29(1): 39-67.

Berrington, A. (2004): Perpetual postponers? Women's, men's and couple's fertility intentions and subsequent fertility behaviour. Population Trends, 117: 9-19.

Berrington, A. (2017): Childlessness in the UK. In Kreyenfeld, M. - Konietzka, D. (eds.): Childlessness in Europe: Contexts, causes, and consequences. Cham: Springer, 57-76. doi:10.1007/978-3-319-44667-7_3.

Brewster, K. L. - Rindfuss, R. R. (2000): Fertility and Women's Employment in Industrialized Nations. Annual Review of Sociology, 26(1): 271-296.

Daróczi, E. (2001): Nők és férfiak korspecifikus termékenységi arányszámai 2000ben. Korfa Népesedési hírlevél. II(3-4), 14.

Egészségjelentés 2016 (2017): http://www.egeszseg.hu/szakmai_oldalak/assets/ intezetunkrol/egeszsegjelentes-2016_uj.pdf (Letöltve: 2018. 06. 22.).

Eurostat (2018): In-work at-risk-of-poverty rate

https://ec.europa.eu/eurostat/tgm/table.do?tab=table\&init=1\&language=en\&pcod e=tespm070\&plugin=1 (letöltve: 2018. 11. 17.).

Fahlén, S. - Oláh, L. (2015): The impact of economic uncertainty on childbearing intentions in Europe. Families and Societies Working Paper Series, 36. http://www. familiesandsocieties.eu/wp-content/uploads/2015/06/WP36FahlenOlah2015. pdf (letöltve: 2018. 06. 22.).

Fasouliotis, S. J. - Schenker, J. G. (1999): Social aspects in assisted reproduction. Human Reproduction Update, 5(1): 26-39.

Fieder, M., - Huber, S. - Bookstein, F. L. (2011): Socioeconomic status, marital status and childlessness in men and women: An analysis of census data from six countries. Journal of Biosocial Science, 43, 619-635.

Gillespie, R. (2003): Childfree and feminine: Understanding the gender identity of voluntarily childless women. Gender and Society, 17(1): 122-136.

Gonzáles M-J. - Jurado-Guerrero, T. (2006): Remaining childless in affluent economics: A comparison of France, West Germany, Italy and Spain, 1994-2001. European Journal of Population, 22(1): 317-352.

Hagestad G. - Call, V. R. A. (2007): Pathways to childlessness: A life course perspective. Journal of Family Issues, 28(10): 1338-1361.

Haskova, H. (2011): The role of work in fertility plans of childless men and women in their thirties. In V. Cuzzocrea - Laws, J. (eds.): Value of work: Updates on old issues. Oxford: Inter-Disciplinary Press, 149-158.

Hegedűs, J. - Teller, N. (2007): Hungary: Escape into home ownership. In Elsinga, M. - De Decker, P. - Teller, N. - Toussaint, J. (eds.): Home Ownership Beyond Asset and Security: Perceptions of Housing Related Security and Insecurity in Eight European Countries. Amsterdam: IOS Press, 133-171. 
Hobson, B. - Fahlén, S. (2009): Competing scenarios for European fathers: Applying Sen's capabilities and agency framework to work-family balance. The Annals of the American Academy of Political and Social Science, 624(1): 214-233.

Hobson, B. - Fahlén, S. - Takács, J. (2011): Agency and capabilities to achieve a worklife balance: A comparison of Sweden and Hungary. Social Politics, 18(2): 168-198. Jalovaara, M. - Fasang, A.E. (2017): From never partnered to serial cohabitors: Union trajectories to childlessness. Demographic Research, 36(1): 1703-1720.

Kapitány B. (2012): 'Látogató párkapcsolatok' Magyarországon. Szociológiai Szemle, 22(1): 4-29.

Kapitány B. (szerk.) (2015): Terjed a gyermektelenség Magyarországon. Korfa Népesedési hírlevél. XV(1),1-4.

Keizer, R. - Dykstra, P. A. - Jansen, M. D. (2008): Pathways into childlessness: Evidence of gendered life course dynamics. Journal of Biosocial Science, 40(1): 863-878.

Kohli, M. (1986): The world we forgot: A historical review of the life course. In Marshall, V. W. (ed.): Later Life. The Social Psychology of Aging. London: Sage.

Kreyenfeld M. - Konietzka D. (eds.) (2017): Childlessness in Europe: Contexts, Causes, and Consequences. Cham: Springer. https://link.springer.com/book/10.1007\% 2F978-3-319-44667-7.

KSH (2015): Születéskor várható élettartam, nemenként (2004-2015). https://www. ksh.hu/docs/hun/eurostat_tablak/tabl/tps00025.html (letöltve: 2018. 06. 22.).

Makay Zs. (2015): Családtámogatás, munkavállalás, gyermeknevelés. In Monostori J. - Őri P. - Spnost Zs. (szerk.): Demográfiai Portré 2015. KSH Népességtudományi Kutatóintézet, 57-75.

Matysiak, A (2011): Interdependencies Between Fertility and Women's Labour Supply. Cham: Springer.

Matysiak, A. - Steinmetz, S. (2008): Finding their way? Female employment patterns in West Germany, East Germany, and Poland. European Sociological Review, 24(1): 331-345.

Matysiak, A. - Vignoli, D. (2013): Diverse effects of women's employment on fertility: Insights from Italy and Poland. European Journal of Population, 29(3): 273-302.

Merz, E.M. - Liefbroer, A.C. (2012): The attitude toward voluntary childlessness in Europe: Cultural and institutional explanations. Journal of Marriage and Family, 74(3): 587-600.

Miettinen, A. - Szalma, I. (2014): Childlessness intentions and ideals in Europe. Finnish Yearbook of Population Research, XLIX: 31-55.

Mynarska, M. - Matysiak, A. - Rybinska, A. - Tocchioni, Vignoli, D. (2015): Diverse paths into childlessness over the life course. Advance in Life Course Research, 25(1): 35-48.

Náday J. (2014): Változnak a szülői felügyeleti jogok az új Ptk. Családjogi könyvében. Jogászvilág, 2014. 03. 27., https://jogaszvilag.hu/rovatok/szakma/valtoznak-aszuloi-felugyeleti-jogok-az-uj-ptk-csaladjogi-konyveben (letöltve: 2018. 06. 22.). 
Neményi M. - Takács J. (2015): Örökbefogadás és diszkrimináció Magyarországon. Esély, 27(2): 32-61.

OECD (2017): State of Health in the EU Country Health Profile 2017. http://www. euro.who.int/_data/assets/pdf_file/0006/355983/Health-Profile-HungaryEng.pdf?ua=1.

Pittini, A. - Ghekiére, L. - Dijol, J. - Kiss, I. (2015): The state of housing in the EU 2015. Brussels: Housing Europe.

Riley, M. W. - Kahn, R. - Foner, A. (1994): Age and Structural Lag: Society's Failure to Provide Meaningful Opportunities in Work, Family and Leisure. New York: WileyInterscience.

Sappleton, N. (ed.) (2018): Voluntary and Involuntary Childlessness: The Joys of Otherhood? Manchester: Emerald Publishing.

Spéder Zs. (2011): Ellentmondó elvárások között. In Nagy I. - Pongrácz T. (szerk.): Szerepváltozások. Jelentés a nők és férfiak helyzetéröl 2011. Budapest: TÁRKI Nemzeti Erőforrás Minisztérium, 207-228.

Spéder, Zs. - Kapitány, B. (2014): Failure to realize fertility intentions: A key aspect of the post-communist fertility transition. Population Research and Policy Review, 33(3):393-418.

Szalma I. (2010): Attitűdök a házasságról és a gyermekvállalásról. Demográfia, 53(1): $38-67$.

Szalma I. (2011): A munkaerő-piaci helyzet hatása az első tartós párkapcsolat kialakítására és a szülővé válásra Magyarországon. PhD-disszertáció. Budapest: Budapesti Corvinus Egyetem, http://phd.lib.uni-corvinus.hu/589/2/Szalma_Ivett_ten.pdf.

Szalma I. (2014): A gyermekvállalás társadalmi normai és a mesterséges megtermékenyítéssel kapcsolatos attitűdök vizsgálata Magyarországon és Európában. Replika, 85-86: 35-57.

Szalma I., Takács J. (2016): Gyermektelenség Magyarországon: Mítoszok és kutatási eredmények. Magyar Tudomány, 177, (2), 159-167.

Szalma I. - Takács J. (2012): A gyermektelenséget meghatározó tényezők Magyarországon. Demográfia, 55(1): 44-68.

Szalma I. - Takács J. (2014): Gyermektelenség - és ami mögötte van. Egy interjús vizsgálat eredményei. Demográfia, 57(2), 109-137.

Szalma, I. - Takács, J. (2015): Who remains childless? Unrealized fertility plans in Hungary. Czech Sociological Review, 51(6): 1047-1075.

Szalma, I. - Takács, J. (2018): Is there voluntary childlessness at all in Hungary? In Sappleton, N. (ed.): Voluntary and Involuntary: The Joys of Otherhood? Manchester: Emerald Publishing Limited, 309-337.

Takács, J. (2013): Unattainable desires? Childbearing capabilities in early $21^{\text {st }}$ century Hungary. In Oláh, L. Sz. - Fratczak, E. (eds.): Childbearing, Women's Employment and Work-Life Balance Policies in Contemporary Europe. Palgrave Macmillan: Basingstoke and New York, 179-206. 
Takács J. (2017): Aktívan törődő apák Magyarországon. Szociológiai Szemle, 27(3): 104-126.

Takács J. (2008): „Ha a mosogatógép nem lenne, már elváltunk volna...” Férfiak és nők otthoni munkamegosztása európai összehasonlításban. Esély, 6: 51-73.

Testa, M. R. (2006): Childbearing Preferences and Family Issues in Europe. Brussels: European Commission.

Trimarchi, A. - Van Bavel, J. (2017): Education and the transition to fatherhood: The role of selection into Union. Demography, 54(1): 119-144.

Van Bavel, J. - Jansen, M. - Wijckmans, B. (2012): Has divorce become a pro-natal force in Europe at the turn of the 21st century? Population Research and Policy Review, 31(5): 751-775.

Vicsek L. (2018): Egyetemi hallgatónők gyermekvállalási tervei és értelmezései a korhoz kapcsolódó fertilitás csökkenésről. Socio.hu, Társadalomtudományi Szemle, 8(3): 80-106. https://socio.hu/uploads/files/2018_3/29_vicsek.pdf.

Widmer, E. D. - Ritschard, G. (2009): The de-standardization of the life course: Are men and women equal? Advances in Life Course Research, 14(1-2): 28-39.

Wiik, K. A. - Dommermuth, L. (2014): Who remains unpartnered by mid-life in Norway? Differentials by gender and education. Journal of Comparative Family Studies, 45(3): 405-424.

Yavorsky, J. E. - Kamp Dush, C. M. - Schoppe-Sullivan, S. J. (2015): The production of inequality: The gender division of labor across the transition to parenthood. Journal of Marriage and Family, 77: 662-679. 